\title{
Negotiating Personal Experience over the Lifetime: Narrative Elasticity as an Analytic Tool
}

\author{
Oriana Bernasconi \\ Universidad Alberto Hurtado
}

\begin{abstract}
Sociology and neighboring disciplines have produced different analytic tools to examine the dialogical relationship between individuals and society ("narrative work," "identity work," "moral career," "moral breakdown"). However, the question of how individuals negotiate the interpretation of personal experience over their lifetimes in a changing cultural context remains unexplored. This article introduces narrative elasticity as a feature of narrative work and as a time-sensitive analytic tool for conducting inquiries into processes of temporal retraction and expansion of what storytellers conceive as the normal order of significance. The application of this tool to the analysis of mature and elderly Chileans' life stories shows how cultural change occurs at the individual level, considers factors that motivate and inhibit processes of reinterpretation of personal experience, and identifies different levels at which it operates.

Keywords: life stories, narrative work, social change, self, morality, temporality
\end{abstract}

Although since its inception sociology has addressed the relationship between social arrangements and the type of self that inhabits them (Rose 1989:xvii), scholarship on selfhood has developed randomly, remains scattered among different schools, and holds only a minor place in this tradition of thought. At least two factors explain this phenomenon. First, sociology often has failed to put the individual subject at the center of analytic work, giving preeminence to collective agents (community, class, or religion) and conceptualizing the person either as a motivational source or as an effect of social processes. In both positions, the individual is considered a given category rather than a problematic, historically contingent, assemblage worthy of analysis on its own (Calhoun 1991). Second, sociological thought has emphasized the theorization of social order, memory, and reproduction, at the expense of the conceptualization of social change and creativity (Touraine 2002). In the twentieth

Direct all correspondence to Oriana Bernasconi, Department of Sociology, Universidad Alberto Hurtado, Cienfuegos 46, Santiago, Chile; e-mail: obernasc@uahurtado.cl.

Symbolic Interaction, Vol. 34, Issue 1, pp. 20-37, ISSN 0195-6086, electronic ISSN 1533-8665. ㄷ 2011 by the Society for the Study of Symbolic Interaction. All rights reserved. Please direct all requests for permission to photocopy or reproduce article content through the University of California Press's Rights and Permissions website, at http://www.ucpressjournals.com/reprintinfo.asp. DOI: 10.1525/si.2011.34.1.20. 
century, however, new developments in the social sciences gradually released the category of the self from the secondary status historically accorded to it by sociology. At the beginning of the century, "Nietzsche and Freud paved the way for the social sciences to regain interest in the self" (Wagner 2002:33): psychoanalysis stressed the internal and symbolic construction of selfhood and located the drives of human development in the psyche, while Nietzsche freed the category of the person from the rules imposed by collective life. In the 1960s, with the contribution of the symbolic interactionists Mead, Blumer, and Goffman, the sociology of selfhood began to develop. These scholars observed the conformation of self-identity in interactional context: Mead ([1934] 1948) conceived of the self as the result of a reflexive process in interactional everyday contexts, Blumer (1969) systematized the idea that meaning is a property of behavior rather than an intrinsic quality of the object, and Goffman (1959) theorized on the order of face-to-face interaction and on the codes of presentation of self among others, emphasizing its performative nature. In European social thought, Foucault's work in the 1970s and 1980s documented the history of subjectivity, analyzing structures of discourse and how their use forms and rearranges the codes of knowledge through which the self is produced. In the last two decades and at a global level, post-structural, feminist, cultural, and critical theories have contributed to issues of central relevance, like the polysemic nature of selfhood and the theorization of agency.

The development of different tools for empirical analysis of the dialogical relationship between self and society has accompanied this process. For example, the relationship between self-interpretation and prevailing social discourses has been examined as narrative work (Fischer-Rosenthal 2000; Holstein and Gubrium 2009) and identity work (Snow and Anderson 1987). ${ }^{1}$ Still, the question of how individuals negotiate the interpretation of personal experience over their lifetimes in the context of cultural change remains unexplored. Sociology's systematic deficit in the area of the sociology of time (Adams 1990), its prioritization of the study of order and reproduction over change and creativity, and the influence in the theorization of selfhood of the long-lasting debate between essentialism and constructivismbasically two ahistorical concepts (McNay 2000:79)—partly explain the lack of systematic work on the relationship between time, self-interpretation, and cultural change. The present article introduces narrative elasticity (NE) both as a feature of narrative work and as a time-sensitive analytic tool for examining the negotiation of personal experience when the cultural references that propelled and nested people's self-conceptions suffer transformations in a given society. It also describes the specificity of NE against existing tools and discusses some outcomes of its use for conceptualizing social change from the individual's viewpoint, both considering factors that motivate or inhibit NE and identifying different levels at which it operates. I glean this analysis from research on the transformation of selfhood and morality through biographical storytelling across three generations of Chilean families. Consequently, the empirical cases presented here refer to NE in the moral orientations of the self-which I term moral narrative elasticity. Beyond this case, NE may be applied 
to other fields of experience. Because NE is a diachronic tool, I also chose to select narrative excerpts from interviews with the older generations in my data set (grandparents in their mideighties and parents in their late fifties).

\section{NARRATIVE ELASTICITY}

Narrative analysts have utilized various resources to explore the relationship between broader cultural discourses and how individuals draw on them to construct personal stories: from a psychoanalytic approach see Frosh's $(1999,2004)$ critical narrative analysis and Hollway and Jefferson's use (2000) of free association techniques; from a feminist perspective see Stanley's (1992) and Tamboukou's (2008) development of auto/biographical theory; in history see Bjorklund's (1998) comparative study of self-presentation in American autobiographies; in sociology see Holstein and Gubrium's $(2000,2009)$ approach to narrative work as interpretive practice, Ellis's (2004) autoethnographic work, Plummer's ([1983] 2001) humanistic concern with personal documents and life-story methods, and Riessman's $(1990,2000,2008)$ exploration of the role of personal narratives in moments of biographical disruption. In the study of this relationship, however, scholars have typically located the person in relational terms, but not necessarily in temporal frames (Charmaz 1991:230), paying no systematic attention to the development of and the investment in a sense of temporal self-continuity (Ezzy 1998:239) in the narrative conception of the individual.

Life stories are discursive practices through which narrators organize, in their concrete social context, first-person accounts of lived experiences over the life course. But personal narratives do not simply "recover the past" as it was experienced and understood when it was lived (Stanley 1992:7); rather, they work to assess that past through a given present that, at the same time, has been constructed and is affected by that past. Koselleck (1983) observed that our way of understanding the past has consequences for interpreting that past itself and for its relation with the present and future. The categories we use to make temporal dimensions "conceivable" are inseparable from our interpretation of those temporalities (Pickering 2004). Additionally, Mead ([1932] 1959) has argued that the "objective past" or the "social structural past" bears conditioning effects on the organization of present experience.

During life-story analysis, I came across excerpts of narrative work that referred to this temporal dimension of self-constitution and, specifically, to the way storytellers apprehend the past under a changing present. I further discovered that, as Taylor (1989) argues, transformations in self-conceptions entailed reinterpretations of personal experience and that, in turn, reinterpretations of experience are associated with redefinitions of the interpretative lines of the biographical account. I began to label this discursive work narrative elasticity.

In Chilean society, profound political, economic, and cultural restructuration over the past four decades has fostered a particularly acute context of cultural change, prompting the reassessment of self-references across generations. Cases of NE in mature and elderly interviewees' stories in particular caught my attention. Because 
people in their late fifties or eighties tend to have less "plasticity" (Boltanski 2000:88) than the youth in these matters (Corsten 1999; Kohli 1996; Mannheim 1952; Pilcher 1994), we might have presumed that these mature and elderly Chileans would not be willing to reassess their life orientations. But some of they did, and questions began to arise: what motivates NE? How do storytellers justify it? To what extent can older generations revise their customized humanity? What does this process involve for their sense of self? What can the reassessment of life experience tell us about how social change occurs at the individual level?

I term the processes of negotiation of the interpretation of personal experience over time and through personal storytelling narrative elasticity, drawing on Holstein and Gubrium's (2000:116-23) book, in which they propose the concept in roughly the same sense I develop it here. NE can be conceptualized as narrative work because it refers to the "active," "purposeful," "practical," and "performative" activity (Holstein and Gubrium 2009) of discursive self-presentation (Fischer-Rosenthal 2000). It can also be described as a type of identity work (Snow and Anderson 1987), because it looks at the construction and negotiation of personal identity in talk. However, if identity work focuses on constructing a worthy self-identity in the context of roles and statuses, NE points to the reinterpretation of personal experience over the lifetime and in relation to new cultural references. In NE work, the narrating subject orients the interpretation of the biographical account in the context of social change, either expanding or stretching the boundaries of the self and going beyond what he or she considers "the normal order of significance" (Pickering 2004) or retracting from this alternative and fixing the cultural references of the past. This time-sensitive aspect of NE makes it a more precise analytic tool than the much broader term narrative work. Because of how it connects life experience, time, and interpretation, NE is, from the storyteller's viewpoint, a "time-constructing" and "time-processing" activity (Fischer-Rosenthal 2000:117). As an analytic tool in the hands of social scientists, NE tries to capture both the individual's reassessment of those standards deemed worthy of endorsing or opposing in a context of social change and the limits of the possibilities of change, including what renders the self resistant to reinterpretation and all that is considered inadmissible when the coordinates that frame the orientations of the self have been modified. In this sense, NE is a time-sensitive tool for studying the durability of certain forms of identity as well as the conditions under which storytellers find the need to compare their present actions with past actions, to reassess the meaning given to the events, and to reinterpret the coherence between past and present experiences (Boltanski 2000:88). Attention is given to the resources (Holstein and Gubrium 1998) needed for reinterpreting personal experience and to the consequences they bear on the relationship individuals establish with themselves, others, and things. This negotiation of the normal order of significance may remain at a discursive level, may involve affirming new values, and may include enacting new practices.

In the relationship between self-identity and biographical time, NE presumes a certain level of plasticity in the individual to reformulate personal orientations 
and institute new practices. Thus the concept presupposes an open-ended notion of self-identity, as opposed to one that remains constant and invariable over time. In social theory, it is perhaps Mead's ([1934] 1948) seminal distinction I/Me that best conceives of temporality as a constitutive dimension of the sociological notion of self. Allowing critical distance between people and their culture, it opens up analytic room for conceptualizing reflexivity and social change. But at the same time, NE takes seriously the role played by ingrained and embodied dispositions, emotional needs, and practical knowledge, as well as the need to maintain a unified sense of self in negotiating life experience over time.

\section{METHODOLOGY}

In "Doing the Self: Selfhood and Morality in the Biographical Narratives of Three Generations of Chilean Families" (2008), I compared biographical stories to study intergenerational transformations and continuities in the moral self. Between 2003 and 2004 I conducted thirty life-story interviews with grandparents, parents, and grandchildren of ten families living in Chile's capital city, Santiago. In each generation, I interviewed equal numbers of men and women and of people adhering to right-wing and left-wing ideologies; most interviewees shared a Catholic upbringing. The grandparents, born between 1925 and 1935, grew up in families composed of, on average, seven siblings; they started working during adolescence and continued to work long after retirement age. The group included peasants, lawyers, miners, union leaders, self-employed housewives, and businesswomen, married or widowed. On average, they married at age twenty-five and had six children. The parents' generation, born between 1948 and 1955, on average married at age twenty-two and had 3.5 children. They averaged fourteen years of schooling, twice as many as their parents. This group included teachers, intellectuals, blue-collar workers, businesspeople, employees, and housewives, married, divorced, or annulled.

In this research, I propose that the moral self can be fruitfully examined through a narrative study of personal stories. Following Taylor (1989), I use the term morality to designate ideas of respect for and obligations to others, but also to refer to those principles orienting individuals according to an idea of the good and guiding a series of their activities: defining situations, assigning them value, motivating actions, discriminating right from wrong or good from bad, and justifying and criticizing positions. Thus, rather than conceive the identity of the self in a neutral space, I locate it in a space defined by distinctions of worth. As practices of "self-description and selfreflection" (Fischer-Rosenthal 2000:115), life stories are particularly appropriate for examining moral experience. The philosophers MacIntyre (1981), Ricoeur (1984), and Taylor (1989) have argued that narratives are a condition for self-interpretation in these substantive terms. The moral experience itself has a narrative structure, as moral sense-making usually takes a narrative form. Because of my research approach, in the next section I use NE to describe temporal expansion and retraction of the moral references of the self in mature and old age. 


\section{MORAL NARRATIVE ELASTICITY IN MATURE AND OLD AGE: NARRATIVE STRETCHING AND CONTRACTION}

The mature and elderly Chilean people I interviewed have lived through turbulent periods of social change, and they have observed how younger generations think and worry about different issues and confront different challenges. But the interviewees have not merely witnessed these transformations, they have experienced how the dispositions imprinted in their bodies, minds, and souls to make themselves subjects of a particular sort have receded into the past (Frisch 1990:33). Expressions such as "we do things the old way" or "this is no longer a world I can identify with" exemplify narrative contraction. Mature and elderly people respond to a changing context retracting toward the cultural references of the past, rejecting alternative interpretations, and reaffirming old ones. They mark this temporal dislocation with respect to current cultural references by saying "we are people from the past" and taking the role of "the extemporaneous" within the "contemporary" (Schütz 1967). In particular, grandfathers, in comparison with grandmothers, held this view, maintaining a strong reluctance to revise the moral boundaries of the self. Most likely, these Chilean men pay much higher costs for relinquishing conventions, as they have to cede a hegemonic social positioning and renounce what they view as the right and good. In contrast, in past decades, Chilean women have had to confront new models of behavior much more abruptly than men have. This tendency may have encouraged grandmothers-more than grandfathers-to differentiate themselves and to innovate with respect to the ideals of their upbringing. Albeit tardily, partially, and timidly, old women-stories could question the restrictive nature of their era's conventions in a way that old men-stories could not.

Most grandmothers I interviewed have timidly allowed the flow of change to infiltrate some aspects of their way of life; they have "adapted to the times," opening up to innovation and the expansion of their horizons despite the practical "difficulties" and ideological contradictions involved in incorporating new ideas and practices of the self late in life. In the next section, I examine some cases of narrative stretching in mature and elderly Chilean women's stories, identifying motives and different planes of elasticity work. The cases traverse various fields of moral decision-making and represent different levels of moral reasoning, from opinions about premarital sex to decisions about whom to invite to tea and behavior regarding the nude body.

The negotiation of moral interpretations that mature and elderly people undertake against the backdrop of new cultural references is a way to do moral work during interpretative practice. In the 1960s Goffman developed the concept of moral career to refer to ways to conceive of selves, including one's own self, in the confines of institutional systems, be they social establishments or complexes of personal and professional relationships. Moral career, Goffman (1961:168) proposed, can be studied by following the person's "moral experience—that is, happenings which mark a turning point in the way in which the person views the world." Moral narrative elasticity also places moral experience as its object of study, but while the term career 
refers to the person's course through life, Goffman emphasizes changes in selfconception according to different institutional settings. If moral career sees the self as residing "in the arrangements prevailing in a social system for its members," moral narrative elasticity—a time-processing activity—concerns individuals' negotiation of their position as historical subjects. Moral career reconstructs the institutional arrangements that produce the self and their impact on individuals' self-reflections, but offers very little to the examination of how persons think about themselves in relation to cultural change. Moral narrative elasticity observes the reinterpretation of personal moral experience through temporally variable discourses of selfhood, focusing on the expansion and contraction of the moral orientations of the self and on the motivational sources at the basis of these exercises of reassessment. In this sense, we might think of moral narrative elasticity as a "cultural tool" (Swidler 1986) that individuals incorporate into their careers so as to gain certain actuality.

Regarding the conceptualization of the motivational sources behind moral work, after the philosophers Heidegger and Badiou, the anthropologist Zigon (2007) identifies the need to get out of moments of "moral breakdown" and back into the "everyday mode of being-in-the-world" as the main motivation for responding to "ethical dilemmas." My analysis points toward other motivational sources. First, in my study moral motivation relates to concrete, highly mediated, and even embodied sensitivities more than to abstract reasoning and decontextualized and disembodied discernment on what is right (Calhoun 1991). Second, as Ricouer (1984) announced, my data show that the reading of personal experience is mingled with the reading of other people's life story. Third, the cases of NE analyzed prove that strong social relations play a part in fostering new readings of a person's moral experience. Fourth, the stories also point to the fact that lifelong, ingrained, embodied dispositions work against intellectual attempts at reinterpreting personal moral experience. Finally, the analysis reveals how cultural change is done at the individual level and on different planes: acceptance of new orientations, adscription to new values, changes in forms of moral reasoning, and incorporation of new practices of the self.

\section{Acceptance of Alternative Orientations}

Eighty-year-old Clara is an upper-middle-class, retired secretary and the mother of eight children. She was widowed in 1972 and moved from Santiago to the coast, near the town where she was born. Clara lives alone in a small flat overlooking the Pacific Ocean; however, she attends services at the local Catholic church and has many close girlfriends with whom she shares tea. She also visits her children's families regularly in Santiago; we met during one of these visits. Before the following excerpt, Clara was talking about the lack of life options for a woman from a monoparental family structure like her, in a society that grants little support to female professional development. ${ }^{2}$ Elaborating on this topic, Clara reflects on the passing of time: 
TABLE 1.

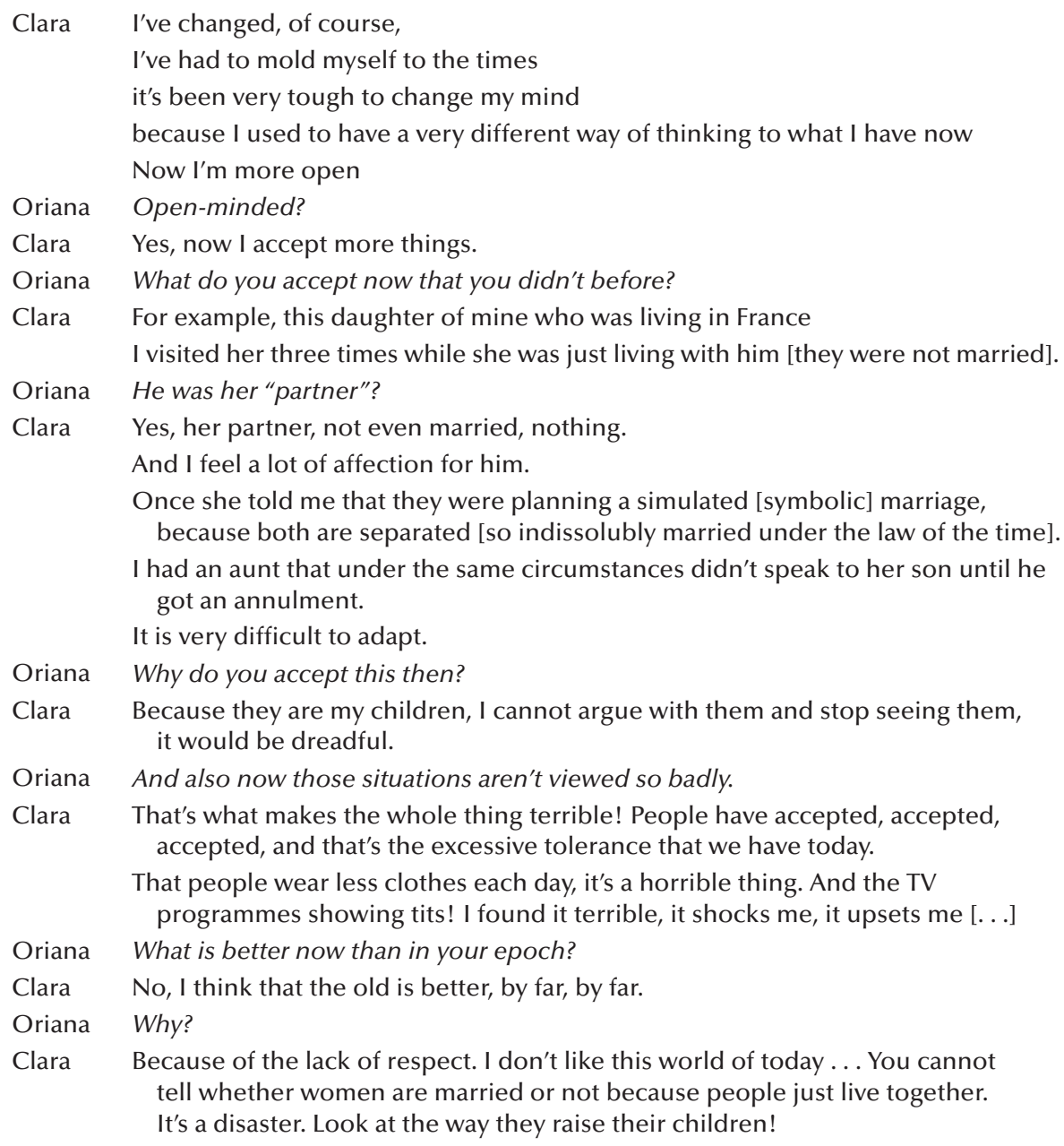

Clara affirms that she has adapted to the new times by developing a more "openminded" approach in her moral evaluations and accepting positions that she used to reject (11. 1-7). This flexibility, however, contradicts the expected moral strength of character on which individuals in Clara's epoch forged personal identity and against which they measured self-worth. Clara's generation asserts that in the Chilean society of the 1920s and 1930s, "staying the same person" throughout one's life secured moral worth. Moreover, the prevailing morality of conformity stated that good people abided by the norm, disregarding personal thoughts, feelings, or aspirations and on pain of social sanction; they had to do "what they must and not what they like," and always felt obligated to consider "what people will say." Perhaps in consideration of this norm, Clara associates the need for change with the demands of the times (1.2) rather than with personal conviction. 
In the story of her daughter's personal life (11. 9-17), Clara says she does not approve of separations and informal unions (not even affection for her daughter's current partner prevents this strong critique). But she also says that it would be "dreadful" to stop talking to her daughter, as her aunt had done under similar circumstances. The story shows that Clara "accepts" alternative orientations not necessarily because she now considers them right but because of the more primordial need to keep her children in her life. In practical terms, the change has been difficult; it has involved alterations in a lifelong mental makeup and a series of ingrained dispositions.

What this grandmother means by acceptance therefore has nothing to do with judging differently or with revising the coordinates that define a good life. In fact, despite my attempts to depict current times as morally favorable toward informal unions, Clara holds a critical vision of current commonsense morality (11. 19-24). When I argue that informal unions are becoming normalized (1. 18), and when I introduce the expression partner to make apparent in our conversation the legitimacy gained by recent changes in family and private life (1.11), Clara diverts with a drastic appraisal of the current moral order. A "shocking" and "upsetting" state of anomie and lawlessness prevails today, a sense of living in an unregulated age.

Clara's case also shows how people negotiate their positions with respect to changing moral frameworks in personal relationships-with children, parents, or partners (Charmaz 1991; Ezzy 1998). Relationships with "significant others" mediate the reassessment of moral dispositions, working as motivational sources for stretching the moral boundaries of the self and showing that, as Calhoun (1991:261-62) argues,

Our moral motivations ... derive in large part not from abstract reason about what is right in general, but from concrete, highly immediate, and even embodied sensitivity to how our actions fit into the relationships we most value.

\section{New Values}

Stretching the moral framework of the self by appropriating new values represents another form of making cultural change at the individual level through narrative work, as Pilar's and Ana's excerpts reveal. When we spoke, Pilar, a member of the second generation, was a fifty-four-year-old middle-class, divorced mother of two young sons. She described herself as a very committed teacher, a family leader, and somebody who seeks peace and contentment in everyday life. At the end of her life story, and in the light of my intergenerational study, I asked Pilar (Table 2) what obstacles her sons' generation has to confront (1. 1). Like Clara, Pilar describes a Chilean society that is "opening up" to alternative ways of life (1l. 2-3), but rather than the issue of heterosexual couples' unions (the subject of Clara's talk), Pilar discusses her attitude toward homosexuality. In her case, however, acceptance is triggered not by the need to maintain key interpersonal relationships but by her conscious attempts to stretch the margins of what she should consider a legitimate way of life. 
TABLE 2

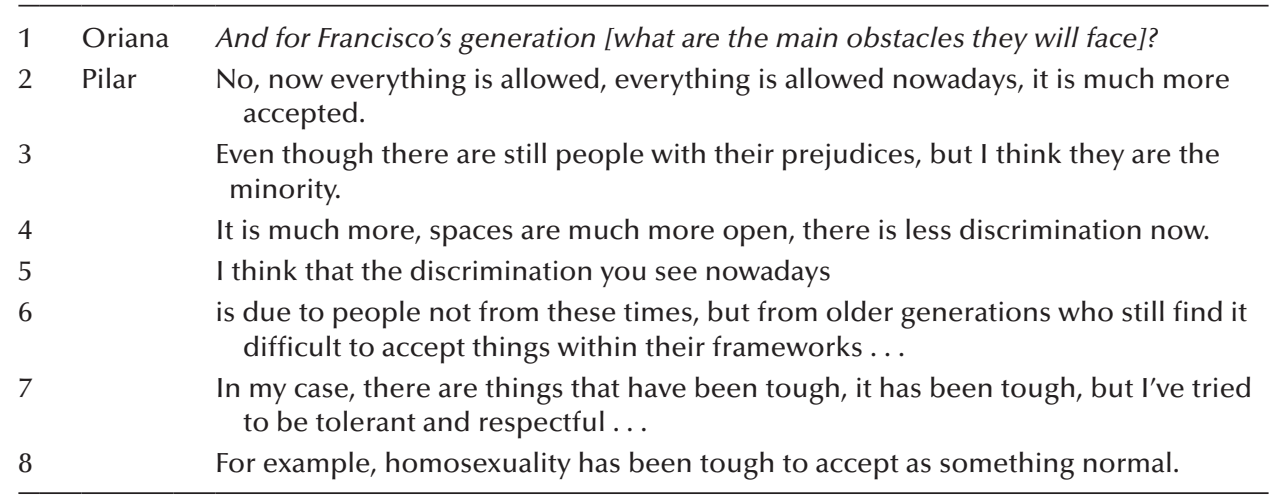

The beginning of Pilar's reflection (1.2) is reminiscent of the grandparents' assessment of current moral parameters: the "excessive tolerance" Clara discussed reverberates behind Pilar's expression "now everything is allowed." After establishing this common ground, Pilar diverts from this form of moral reasoning, because it discriminates against and prejudges people, and establishes temporal distance from it: this is an updated mode of judgment common to older generations' way of thinking (11.3-6). The attitude of a contemporary mind is to stand by the principles of equal treatment. Pilar is convinced that she should uphold the values of "respect" and "tolerance" toward others (1l. 7-8). To this end, she is willing to learn not "to discriminate" and to "accept as normal" those who have different sexual orientations.

At the age of eighty, grandmother Ana, a widow and mother of six, distributes her time between her small flat in an upper-middle-class Santiago neighborhood and the family's plot of land in a southern region, where she runs a small-scale business that provides her living. Speaking about her present life, Ana comments:

TABLE 3.

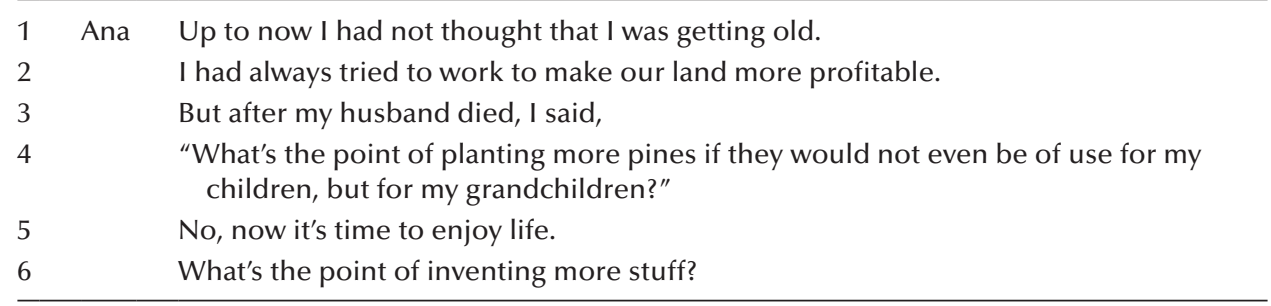

When she no longer has to care for her husband, grandmother Ana opens up to the idea that a woman should enjoy her life (1.5). She sees little value in devoting her time to economic investments for her descendants (1.4). Behind her lie decades of "sacrifice," "suffering," and continuous devotion to her family's welfare. The value Ana 
attributes to personal enjoyment late in life indicates a partial revision of the opposition between care of self and care of others as well as the centrality of customary duties in daily life's organization, both features typical of her generation's narratives. As they tell it, being a good person within this moral outlook requires sacrificing oneself for others, especially one's family; practices such as self-knowledge, self-affirmation, self-expressiveness, and love for the self are classified as "hedonistic."

Clara's, Pilar's, and Ana's excerpts indicate a way to stretch the (moral) boundaries of the self and its operation at different levels. With the passing of time, these mature women have come "to accept" other ways of life that neither they nor their society previously valued. In Clara's case, acceptance involves a change in strategy of action and not a change of value orientation; for Pilar and Ana, it is associated with reformulating personal convictions.

\section{Change in Form of Moral Reasoning}

The following cases from grandmothers Ana and Clara allude to changes in their habitual form of moral reasoning, leading to new social practices that do not necessarily involve - at least explicitly_redefining the idea of the good. In contrast to the past, these grandmothers today present themselves as moral agents making decisions according to personal will and choice ("what I want"), rather than according to the will of others and the law of an ethics of conformity.

TABLE 4.

\begin{tabular}{lll}
\hline 1 & Ana & At this stage in life one can say \\
2 & & "I should invite Mary, but I don't want to, she bores me, what a drag." \\
3 & Oriana & So you don't invite her? \\
4 & Ana & No! This means that one does what one wants and is not worried about what \\
& & others will say or about what is right \\
5 & & ... now I live to enjoy life.
\end{tabular}

TABLE 5.

\begin{tabular}{lll}
\hline 1 & Clara & Now I say when I dislike something. \\
2 & & In those times it didn't matter whether I liked doing something or not \\
3 & but at least I was entertained. \\
\hline
\end{tabular}

Ana and Clara say that they themselves allowed this shift to occur, not granting much importance to what others think and contravening the deber ser (what ought to be done in the eyes of others), especially when that has gone against their will (Ana, 1. 4; Clara, 11. 1-2). They now dare to avoid spending time with people they dislike (Ana) and doing things they do not enjoy (Clara). At this stage in life, these grandmothers likely feel less obliged to prove anything to anybody. Both affirm that the self has always had deliberative powers, but in the 
past external authoritative voices kept these powers "tamed" or "domesticated." However, Ana and Clara remain ambivalent as to whether there is value in this change in moral reasoning. In Ana's quote, the "right" tends to lie on the side of "what others will say" and not with the merits of following her inner voice and enjoying life (11. 4-5). Clara maintains that she has done many things in life without concern for her tastes and preferences; however, instead of using this claim to support her critiques, she affirms that these decisions have kept her entertained, which is a good thing (1.3).

The way upper-middle-class Elena justifies her changed opinion about premarital sex is a significant example of how intergenerational reevaluations of human activity affect mature people's moral reasoning. Elena, a fifty-five-year-old businesswoman, married, mother of three, explains that she opposed premarital sexual relationships not because she thought they were wrong per se and wanted to defend virginity as a principle but because she wanted to save her daughters from the social ostracism meted out to those who acted against society's prescriptions. In the prevailing mentality of Elena's times, husbands used female, premarital, sexual experiences to denigrate nonvirgin, "loose" wives. However, she explains:

TABLE 6.

\begin{tabular}{|c|c|c|}
\hline 1 & Elena & I have talked to my daughters and it seems that nowadays \\
\hline 2 & & men's and women's opinion about premarital sex is different \\
\hline 3 & & and that they consider that both [men and women] ... \\
\hline 4 & & have the right to enjoy their respective sexuality \\
\hline 5 & & and this is no longer employed to reproach women. \\
\hline 6 & & If this is the case, then it's OK. Great. \\
\hline
\end{tabular}

Once female premarital sex is disentangled from the moral censure that equates sexually active single women with dishonor (1.1-5), Elena can accept her daughters' sexual behavior (1.6). The lifting of the social sanction that surrounds the practice enables Elena to approve of her daughters' premarital sexual activity. In sum, these cases show that narrative expansion can manifest in new forms of moral reasoning, even ones that go against habitual forms. This shift, however, does not necessarily involve redefining the individual's hierarchy of values.

\section{New Practices}

A human being's individuality is "equipped" (Thévenot 2002) with forms of mental and bodily activity, understanding and know-how, habits and patterned behavior; it is structured by different "subjectifiers" (Latour 2005) through which to speak, think, and relate in specific ways. ${ }^{3}$ The possibility of trying out different courses of action has to do not only with changes in the form of moral reasoning but also with having the appropriate cognitive, motivational, and emotional resources. 
For Ricoeur it is in the realm of practical imagination that individuals try out their capacity to do something new, in the sense that "I could have done otherwise if I had wanted" (McNay 2000:99). In the context of a conversation about her appraisal of intergenerational changes in Chileans' moral frameworks, grandmother Clara shares a story about a change of bodily practice (11. 9-21) while commenting on the aesthetic value of the nude human body (ll. 1-8). She has always found human bodies to be "awful," most likely because of a socialization in which she learned to associate care of self with sexual disembodiment and the naked female body with moral fault ("sin" and "shame"). Until the age of eighty-two, Clara never appeared naked in front of anybody. But one year ago she did:

TABLE 7.

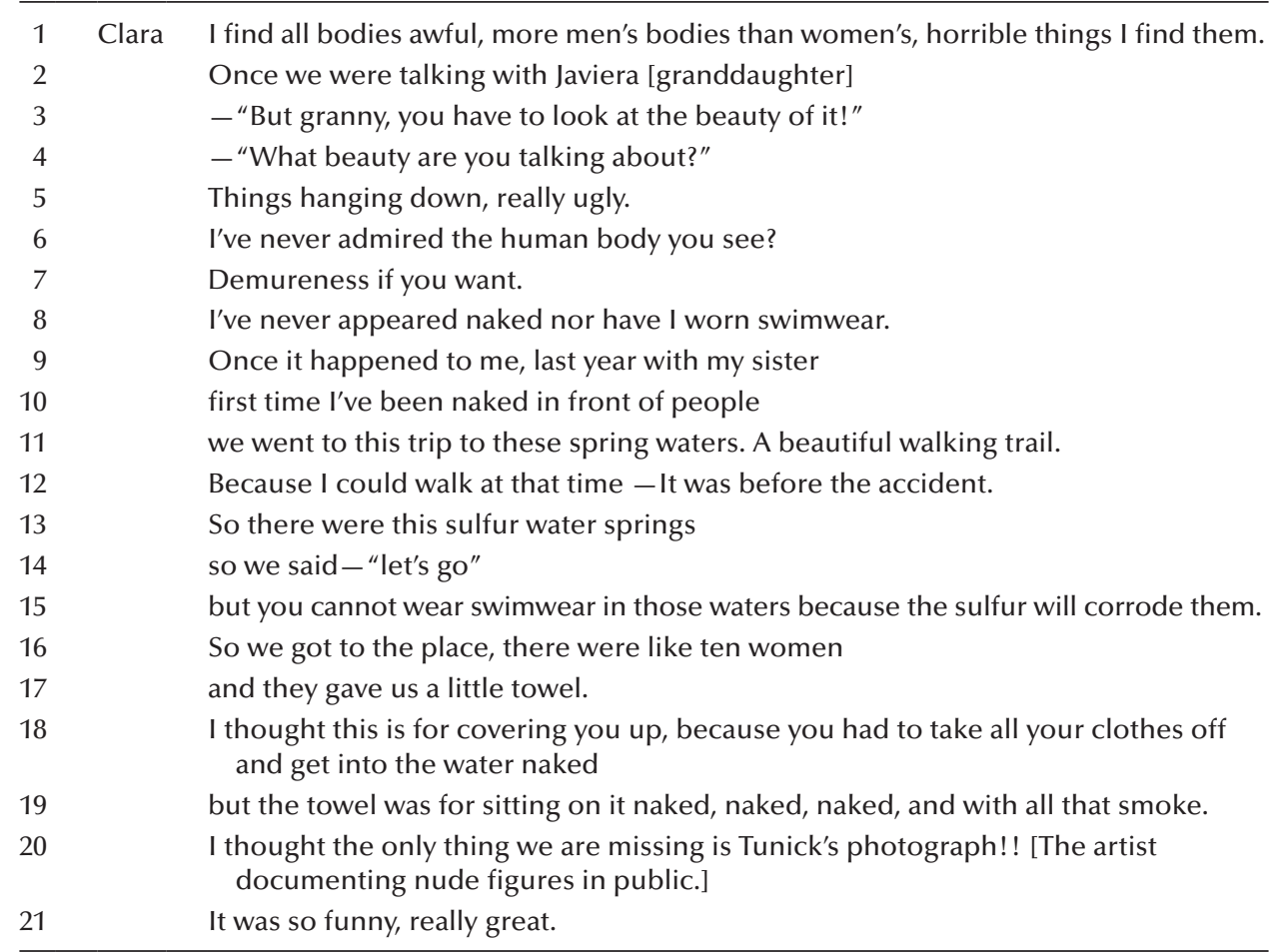

Clara's story demonstrates a contrast between the description of a profoundly ingrained practice (in the span of eighty years she had never shown her nude body [1.8]) that is supported with a drastic aesthetics appreciation (the naked human body is "awful," males especially [1l. 1,5]) and the lightness with which she evaluates the experience of appearing naked in public for the first time in life at the age of eightytwo, as represented by the humor with which she closes the story (the artist Tunick missed a good opportunity of a collective human nude portrait [1.20]) and her positive appreciation of the experience (1.21). McNay's reflection on Castoriadis's elaboration of society's imaginary capacity provides analytic orientation for this case of 
NE. For Castoriadis (2000:100), "Imagination is constitutive not just of individual action, but also of intersubjective relations and collective forms of action." Clara is not trying another course of action alone; with ten other naked women she produces a joined "performance" (Goffman 1959) in the form of a collective nude portrait.

\section{Limits of Narrative Elasticity: The Power of Ingrained Dispositions}

In contrast to Clara, the majority of the grandmothers I interviewed had difficulty embracing what they now consider a "less ignorant" view of the sexual body. In hindsight, they remark that the dispositions routinized since socialization thwarted their desire to institute another type of bodily practice. Swidler (1986) elaborates this point, stating that certain cultural competence is needed to move around (moral) communities, and certain skills are required to adopt different lines of conduct. Grandmother Margarita's account shed light on the conditioning effect of the "social structural past" (Mead [1932] 1959), when dispositions deeply ingrained over time inhibit negotiating moral experience and the institution of new practices. But it also illustrates how emotions and personal relationships can trigger changes of attitude late in life. Margarita was born in the north of Chile in 1907. Raised by her mother-a housekeeper who had twenty children - and her mother's second partner, a railway company employee, she grew up in mining towns and attended school only through fifth grade. Yet unlike other women from the same epoch and similar backgrounds, Margarita's engagement with the world was rich and complex. She had a successful career as a sales employee and an accounting assistant before becoming sole manager of a factory that she and her husband established, a position she held until her retirement at age eighty-two.

Discussing changes in society's attitudes, Margarita comments that she prefers how kids are brought up today "because they talk about their body and name its organs"; that she no longer thinks that touching, showing, talking, sensing, or learning about the naked female body is sinful; and that she "feels ashamed" of such dispositions: however, these associations are so deeply inscribed in the way she relates to her body that a true change of attitude is unlikely. Her upbringing has left her with an ignorance and embarrassment of this subject, which prevents Margarita even from naming sexual organs. At the pediatrician's office she often felt uncomfortable when removing her children's clothes for examinations. During her forty-year marriage, she never allowed her husband to see her naked; they had sex with the lights off and she saw him naked only once because he was so old and sick that Margarita had to bathe him. In recent years, she suffered from a problem in her vagina that required medical self-examinations, but she has not been able to look "down there." Intellectually, she wants to overcome these reservations, but in practice they "come from too deep inside" to do so. Margarita has no sexual vocabulary, has never explored her body or developed a relationship with it, and still views it as a heavy moral burden. Only once, when her husband threatened to find another woman if she kept concealing her body from him, did she concede, and did so strictly out of jealousy: 
TABLE 8.

\begin{tabular}{lll}
\hline 1 & Margarita & You see, with my husband, I was told at home not to. \\
2 & Oriana & So he never saw you [naked]? \\
3 & Margarita & No. Once he told me that he didn't love me anymore. \\
4 & & Oh my lord! I start praying and praying. \\
5 & Oriana & Did you finally allow him? \\
6 & Margarita & Of course I did, but he asked only once. \\
\hline
\end{tabular}

As in Clara's story about her daughter's informal unions, Margarita's narrative about explicit acknowledgment of her body in her marital sexual life reveals how personal moral orientations are negotiated over time in the relationship between self and significant others. Their stories indicate the motivational force of personal relationships and the emotions they generate in stretching the boundaries of the self. The need to maintain bonds with family members, and emotions such as fear of loss and jealousy, motivate the reassessment of what Clara is able to "accept" and of what Margarita is able to "do." Considering these questions, Illouz (2007) argues that because a major part of social dispositions is also emotional dispositions, a hermeneutic sociology should attend to the emotional color of actions- an "internal energy" most of the times prereflexive and semiconscious but exuding culture and society. The analysis of moral narrative elasticity supports Illouz's claim. Yet Margarita's case also attests to how the lack of practice in other modes of being and of relating, together with the possible loss of coherence involved in adapting one's modes to different subjectifiers, limits the intellectual attempt to reread one's moral experience and go beyond one's customized humanity.

\section{CONCLUSIONS}

Narrative analysis, particularly when based on biographical stories, encourages sociologists to work with a temporalized notion of selfhood. Under the assumption that individuals actively engage in interpreting their life experiences in the context of a dialogical relationship between personal stories and social discourses, a narrative study of selfhood focuses on the evolving interpretation of the self through time. In this article, I introduce narrative elasticity, a diachronic tool for qualitative analysis of personal accounts. Building on Taylor, I argue that transformations in self-conceptions entail reinterpretations of personal experience and that these reinterpretations presuppose redefining the interpretative lines of the biographical account. NE relates to this type of narrative work. In assembling personal stories over their lifetimes, and in the light of new cultural references, storytellers may retract toward past interpretations, or they may engage in reevaluating their past experiences, stretching what they once conceived as the normal order of significance. Thus, during NE work, notions of temporal distance and temporal proximity to the present are established, and social change occurs. I propose to use this feature of narrative work 
as an analytic entry point for inquiries into how individuals produce social change by negotiating self-identity in changing cultural contexts. In this light we can examine the motivations and resources narrators draw on as well as the consequences this negotiation bears for the individual concerned.

In comparison with those who conceptualize cultural change either in terms of the impact of macro-structural tendencies on the individual or in terms of personal consistency or inconsistency, NE shows how both these levels coalesce in articulating the personal story: personal consistency is defined around social parameters as much as historical change occurs in the everyday structuring of individual orientations. In this sense, NE belongs to those analytic efforts to trace the social at the individual level, not so much to depict the "big social"-if this remains the aim of examining "big stories" through "little stories" (Holstein and Gubrium 2009)—but to describe how individuals mobilize social change (Latour 2005).

As I applied it here, NE examines the aging of generations in relation to the supersession of the moral frameworks of the self; however, it also can be applied to other areas of reinterpretation of personal experience over time, such as a person's career after career breaks or the relationship to one's culture after a migration process. Moral narrative elasticity shows that cultural change is done at the individual level on a wide range of planes; it can take the form of acceptance of different values (without subscribing to them), adscription to new values, change in the form of moral reasoning, and incorporation of new practices. It also identifies inhibiting factors and motivational sources behind narrative stretching-beyond the need to "go on" with life that Zigon (2007) proposes. First, as Calhoun (1991) suggests, moral motivation relates to concrete, highly mediated, and even embodied sensitivities, more than to abstract reasoning and decontextualized and disembodied discernment about what is right. Second, those significant others with whom my life and narrative intersect play a role not only in the conformation of my moral experience but also in fostering new readings of my life and of my moral intuitions. Third, after the moral breakdown, the return to the "unreflective state" can take a long time. It may require a testing of new orientations against concrete situations in different social contexts, and it may involve restructuring the relationship with oneself and others. Undoubtedly, a different ordering attempt emerges after the moral breakdown, but certainly it will be one compatible with what the person knows and is able to do, endure, and transform. As a discursive practice, NE does not solely depend on mental reasoning but also on embodied dispositions, forms of knowledge, and demands for self-coherence. Moreover, it is not a process the individual undertakes in isolation. To the contrary, my analysis points toward the need for deepening research on the intersubjective frameworks around which cultural parameters are reproduced and transformed, especially if, as Calhoun (1991:262) argues, social relationships mediate the reinterpretation of experience and become "moral sources," that is, to the extent to which in moral reasoning people consider how their actions fit into their most significant relationships. 
Acknowledgments: A preliminary version of this article was presented at Victoria University. Thanks to the Australian Narrative Network and to those who commented on my work there. My appreciation goes to Cathy Riessman and Ruth Ballardie for invaluable insights and encouragement. I am sincerely grateful to the anonymous reviewers for their constructive comments and rich suggestions.

\section{NOTES}

1. Or "vocabulary of motives" (Mills 1963), "inventories of experience" (Mannheim 1952), "narrative environments" (Holstein and Gubrium 2009).

2. In the interview excerpts, ellipses within brackets [...] indicate a cut from the original transcript. Following the interviewee's speech rhythm, I separated clauses on lines (ll.), so as to focus more closely on what was said and elaborate on discursive elements that in paragraph extracts could have passed unnoticed. This separation also facilitates identifying sentences in the analysis.

3. "Subjectifiers" is a concept from Latour's vocabulary. It is similar to "personalisers" and "individualisers," as well as to "plug-ins," the one with which he chooses to work. All allude to those "vehicles that transport individuality, subjectivity or personhood" (Latour 2005:207).

\section{REFERENCES}

Adams, Barbara. 1990. Time and Social Theory. Cambridge: Polity.

Bernasconi, Oriana. 2008. "Doing the Self: Selfhood and Morality in the Biographical Narratives of Three Generations of Chilean Families." Ph.D. thesis, London School of Economics.

Bjorklund, Diane. 1998. Interpreting the Self. Chicago: University of Chicago Press.

Blumer, Herbert. 1969. Symbolic Interactionism: Perspective and Methods. Englewood Cliffs, NJ: Prentice-Hall.

Boltanski, Luc. 2000. El amor y la justicia como competencias: Tres ensayos de sociología de la acción. Buenos Aires: Amorrortu Editores.

Calhoun, Craig. 1991. "Morality, Identity, and Historical Explanation: Charles Taylor on the Sources of the Self." Sociological Theory 9(2):232-63.

Charmaz, Kathy. 1991. Good Days, Bad Days: The Self in Chronic Illness and Time. New Brunswick, NJ: Rutgers University Press.

Corsten, Michael. 1999. "The Time of Generations." Time and Society 8(2):249-72.

Ellis, Carolyn. 2004. The Ethnographic I: A Methodological Novel about Autoethnography. Walnut Creek, CA: AltaMira.

Ezzy, Douglas. 1998. “Theorizing Narrative Identity: Symbolic Interactionism and Hermeneutics.” Sociological Quarterly 39(2):239-52.

Fischer-Rosenthal, Wolfram. 2000. "Biographical Work and Biographical Structuring in PresentDay Societies." Pp. 109-25 in The Turn to Biographical Methods in Social Science, edited by P. Chamberlaine, J. Bornat, and T. Wengraf. London: Routledge.

Frisch, Michael. 1990. A Shared Authority: Essays on the Craft and Meaning of Oral and Public History. Albany: State University of New York Press.

Frosh, Stephen. 1999. “What Is Outside Discourse?” Psychoanalytic Studies 1(4):381-90.

Frosh, Stephen and Peter Emerson. 2004. Critical Narrative Analysis in Psychology: A Guide to Practice. London: Palgrave Macmillan.

Goffman, Erving. 1959. The Presentation of Self in Everyday Life. Middlesex, UK: Penguin Books. . 1961. Asylums: Essay on the Social Situation of Mental Patients and other Inmates. New York: Anchor Books Edition.

Holstein, James and Jaber Gubrium. 1998. "Narrative Practice and the Coherence of Personal Stories.” Sociological Quarterly 39(1):163-87. . 2000. The Self We Live By: Narrative Identity in a Postmodern World. Oxford: Oxford University Press. 
2009. Analyzing Narrative Reality. Los Angeles: Sage.

Illouz, Eva. 2007. Intimidades congeladas: Las emociones en el capitalismo. Buenos Aires: Katz Editores.

Kohli, Martin. 1996. The Problem of Generation: Family, Economy, Politics. Public Lecture No. 14, Collegium Budapest/Institute for Advanced Studies.

Koselleck, Reinhart. 1983. Future Past: On the Semantics of Historical Time. New York: Columbia University Press.

Latour, Bruno. 2005. Reassembling the Social: An Introduction to Actor-Network-Theory. Oxford: Oxford University Press.

Macintyre, Alasdair. 1984. After Virtue. Notre Dame, IN: University of Notre Dame Press.

Mannheim, Karl. 1952. "The Problem of Generations." Pp. 276-322 in Essays on the Sociology of Knowledge, edited by Kecskemeti. New York: Oxford University Press.

McNay, Lois. 2000. Gender and Agency: Reconfiguring the Subject in Feminist and Social Theory. Cambridge: Polity.

Mead, George H. [1932] 1959. The Philosophy of the Present. La Salle, IL: Open Court. - [1934] 1948. Mind, Self, and Society from the Standpoint of a Social Behaviorist. Chicago: University of Chicago Press.

Mills, Charles W. 1963. Power, Politics, and People: The Collected Essays of Charles Wright Mills, edited by L. Horowitz. London: Oxford University Press.

Pickering, Michael. 2004. "Experience as Horizon: Koselleck, Expectation, and Historical Time." Cultural Studies 18(2-3):271-89.

Pilcher, Jane. 1994. "Mannheim’s Sociology of Generations: An Undervalued Legacy.” British Journal of Sociology 45:481-95.

Plummer, Kenneth. [1983] 2001. Documents of Life-2: An Invitation to a Critical Humanism. London: Sage.

Ricoeur, Paul. 1984. Time and Narrative. Chicago: University of Chicago Press.

Riessman, Catherine. 1990. Divorce Talk: Women and Men Make Sense of Personal Relationships. New Brunswick, NJ: Rutgers University Press. . 2000. "Stigma and Everyday Resistance Practices: Childless Women in South India." Gender and Society 14:111-35. 2008. Narrative Methods for the Human Sciences. London: Sage.

Rose, Nikolas. 1989. Governing the Soul. London: Free Association Books.

Schütz, Alfred. 1967. The Phenomenology of the Social World. Evanston, IL: Northwestern University Press.

Snow, David and Anderson Leon. 1987. "Identity Work among the Homeless: The Verbal Construction of Avowal of Personal Identities." American Journal of Sociology 92(6):1336-71.

Stanley, Liz. 1992. The Auto/biographical I: The Theory and Practice of Feminist Auto/biography. Manchester: Manchester University Press.

Swidler, Ann. 1986. "Culture in Action: Symbols and Strategies." American Sociological Review 51 (April): 273-86.

Tamboukou, Maria. 2008. "Re-imagining the Narratable Subject." Qualitative Research 8(3):283-92.

Taylor, Charles. 1989. Sources of the Self: The Making of the Modern Identity. Cambridge, MA: Harvard University Press.

Thévenot, Laurent. 2002. "Which Road to Follow? The Moral Complexity of an 'Equipped' Humanity." Pp. 53-87 in Complexities: Social Studies of Knowledge Practices, edited by J. Law and A. Mol. Durham, NC: Duke University Press.

Touraine, Alain. 2002. "From Understanding Society to Discovering the Subject." Anthropological Theory 2(4):387-98.

Wagner, Peter. 2002. "Selfhood and Identity as a Problématique." Pp. 32-55 in Identities: Time, Difference, and Boundaries, edited by H. Friese. New York: Berghahn.

Zigon, Jarrett. 2007. "Moral Breakdown and the Ethical Demand: A Theoretical Framework for an Anthropology of Morality." Anthropological Theory 7:131-50. 